\title{
Islamic Investment and How to Take Advantage of Capital (The Case of Global Merchants in the City of Mataram, Lombok, Indonesia)
}

\author{
Busaini $^{1}$ \\ 1 Faculty of Economics, Universitas Mataram, Indonesia \\ *Corresponding author. Email; busainidr@gmail.com \\ Manuscript submitted August 04, 2014; accepted October 13, 2017.
}

\begin{abstract}
This paper describes how the economic development of Islam in Indonesia and Islamic investment offender, specific investment is viewed from two musty mudharabah and ijarah. We know people are familiar with conventional investments that rely on the interest rate, but the author tries to see a bunch of people who do not invest based on the interest rate. Community groups in question are gold and pearl merchants in the city of Mataram; they traded with the islamic law principle informed with the actual quality of the goods, weighing, and make an appointment with either. Associated with investments, they provided capital among traders with profit sharing agreement at the end of the year, 60 percent to 40 percent owner of capital for business managers. Labor they take an average of 2 people for each trader with wage system 50 thousand rupiahs per day. Contribution to the development of economic gold traders Mataram is helpful in employment, supporting the development of West Nusa Tenggara Tourism, both domestic and abroad, especially in the area of increased income tax payments, an increase in the welfare of the community with many traders who perform the Hajj.
\end{abstract}

Keywords: Islamic investments, Murabaha, ijarah, contribution and profit sharing

\section{Introduction}

Indonesia is one country whose population number four in the world, and the majority Muslim population. This condition is very potential for the development of Islamic investment depends on community participation. Habits of Indonesian people still faced with the old habit of investing with a focus on interest rates. To eliminate this habit is to promote economic activities that are lawful Islamic, whether in production, consumption, and distribution.

With the establishment of Islamic banks in Indonesia to provide fresh air for the development of Islamic economics, especially in investment activities. A glimpse of the Islamic economic system in the world and Indonesia can briefly describe.

The economic system over the world usually is influenced by philosophical, ideology, religion, and political interest. Economics is a study how to achieve welfare and how to distribution. Welfare means something has value and price include goods and services that are produced and traded 
by a businessman. To distribution goods and services are determined by the economic system. We have already known economic system over the world, capitalism, socialism, and the last Islamic Economic System.

Over the world, the famous terminology is Islamic Economic, but in Indonesia islamic law Economic, because in 1990 islamic bank was built for the first time that founded by Majelis Ulama Indonesia (MUI) or Indonesian Cleric Assembly and ICMI (Indonesian Muslim Intellectual Ties).

At the core of the Islamic Economic System lies a collection of rules and institutions which affect economic behavior and outcomes. The islamic law defines this core.

A central aspect of the Islamic Economic System is the emphasis placed on justice. It is via justice the rules governing the economic behavior of the individual and economic institutions in Islam can be understood. Justice in Islam is a multifaceted concept, and the exist several words to define it. The most common word used which refers to the overall concept of justice is " adl". This word and its many synonyms imply the concepts of "right", as equivalent to fairness, "putting things in their right place," "equality," "balance," "temperance" and "moderation." In practice, justice is as acting by the Law, which in turn contains both substantive and procedural justice covering economic issues. Substantive justice consists of those elements of justice contained in the substance of the Law, while procedural justice consists of rules of procedure assuring the attainment of justice contained in the substance of the law. The notion of economic justice and its attendant concept of distributive justice is particularly important. An identifying characteristic of the Islamic Economic System because rules governing permissible and forbidden economic behavior on the part of consumers, producers and government, as well as questions of property rights and production and distribution of wealth, are all based on the Islamic view of justice.

The first basic principle of property in Islam is that Allah is the ultimate owner of all property. So that man becomes materially able to perform his duties and obligations, he has given the right of possessions. The second principle of property, therefore, establishes the right of the collectivity to the resources at man"s disposal, based on the principle of justice. The recognition of man's natural tendencies, right, and obligations, individuals are allowed to appropriate for themselves. The products are resulting from the combination of their labor and certain of these resources- without the collectivity losing its original rights either in the resources or the products resulting from the individual" s creative labor applied to these resources- by the rules, specified by islamic law. The Islamic law also determines which natural resources retained as the exclusive property of the collectivity and which resources, and in what amount, will be at the disposal of individual members of the society.

Islam contends that adherence to the rules specified by the sharia will generate widespread economic benefits. These benefits include a strong work ethic, honest business dealings, efficient production, non-extravagant consumption, distributive justice, productive circulation of accumulated surplus with full participation in risks and rewards, full compliance with terms of contracts, and maximum cooperation in economic activities with complete freedom of contracts within the bounds of islamic law.

\section{Literature Review}

\subsection{Islamic Economics: A Solution to Current Crisis}

A growing trend of dissatisfaction with conventional economics has raised interests in finding an alternative paradigm leading to the revival of Islamic economics over the last few decades. On 8 August 2012, Dr. Izzuddin Edi Siswanto explained how Islamic economics might provide solutions to 
existing problems in the financial markets as well as its contribution and potentials to address development challenges.

The conventional economics and financial systems have put to the test following recent global financial crises. George Soros, a global financier, and philanthropist viewed:

"There is a super bubble that has been going on for 25 years, or so that started in 1980 when Margaret Thatcher became Prime Minister, and Ronald Reagan became President. That is when the belief that markets left to their own devices became the dominant belief. Based on that we had a new phase of globalization and liberalization of financial markets.

The idea is false. Markets do not correct towards equilibrium." "The whole construct, this really powerful financial structure, has been built on false grounds. For the first time, this entire system has engaged in this economic crisis."

Prof Zubair Hassan, a prominent Islamic economics scholar, argued that current world situation has been solid proof of the failure of capitalist economic systems to improve equality and welfare. The capitalist system has created massive capital accumulation in the last five decades since 1950, far bigger than the capital accumulated from the period of the prophet Adam to 1950.

Dr. Siswanto argued that the capitalist system has caused excessive leverage and speculation leading to what called as the inverted pyramid of wealth and debt positioning welfare at the bottom of the inverted pyramid and debt gaining the biggest portion at the top of the inverted pyramid. He further argued that debt accumulates faster than wealth and minor shocks can make the system crash. The financial systems become fragile. Crashes are needed to "clean up" the system. Then, debts start to accumulate again faster than wealth recurring crashes.

From an Islamic economics" point of view, there are at least two sources of danger: Riba (usury and interest on loans) and Gharar (gambling and wagering). The danger of Riba is due to several reasons: it separates debt creation from wealth creation; debt grows faster than wealth; debt maturities shorter than assets, and debt services become unbearable. Riba also shrinks the real sector causing lower production and therefore increasing inflation which can lead to lower economic growth. The danger of Gharar or gambling is due to its high transaction costs. Gambling is also a zero-sum game where one" s profit causes the other party" s loss. Given this criterion, Islamic economics excludes derivatives as they are essentially zero-sum games.

In contrast, a Islamic law-based system aims to improve wealth and income distribution as well as the development of real sectors. In Islamic economics, debt creation integrated with wealth creation. Moreover, excessive risk and zero-sum games excluded. Also, finance integrated with real transactions. Since real sectors are less risky than financial markets, Islamic finance is less risky than conventional finance.

Islamic law financial products are developed based on three main strategies: (i) modification of conventional products; (ii) innovative Islamic-based products; and (iii) products developed to respond demand from consumers. Those Islamic products must possess acceptable risk (ex-ante) as indicated by the high likelihood of success and inseparable from real activities. They must also have a clear payoff structure (ex-post).

Islamic economics also acknowledges the importance of social safety nets. The non-profit safety net integrated into economic activities. Zakat or almsgiving, as well as interest-free lending, are common tools to help the poor access capital.

The development of Islamic economics must face some challenges. Pessimists often perceive that the difference between Islamic economics and conventional economics is not clear. Some view that it is simply a matter of "branding." Others raise concerns about the competitiveness of Islamic 
banking because at the end of the day consumers always want to obtain profits. Islamic financial institutions must also keep looking for innovative products. The condition is often difficult considering the lack of human capital. Islamic supervisory boards often filled with those whose expertise is only in Islamic laws but have limited knowledge of economics. Having said that, looking at positive trends since 2000 in the development of

Islamic financial sectors in Indonesia, as well as Indonesia"s growing middle-income groups, Islamic financial products, should have profitable markets in the country.

From the above description want to see how Islamic investment and how to take advantage of capital. Investment is the active form of Islamic economics because each property is no zakat if the property will be consumed gradually silenced by zakat, one of the lessons of charity is encourage for every Muslim to invest his money, invested assets not consumed by the charity, but the benefits are.

We know the price of the investment, the price is the value of the sale or purchase of something that traded, the difference between the purchase price to the selling price is called the profit margin, price formed in the aftermath of the market mechanism.

Al-priest according to Al-Ghozali, profit is the compensation of the exhaustion of travel, business risk and personal safety threats entrepreneurs, so it is reasonable for someone to gain the benefits of risk borne compensation.

According to Ibnu Taimiah, offers could come from domestically and imported products, changes in supply described as an increase or decrease in the number of goods on offer, while the demand is very determined and revenue expectations, depending on the size of price increases and the magnitude of changes in supply or demand. When all transactions are by the rules, the price increase happens God"s will.

Islamic laws but have limited knowledge of economics. Having said that, looking at positive trends since 2000 in the development of

Islamic financial sectors in Indonesia, as well as Indonesia"s growing middle-income groups, Islamic financial products, should have profitable markets in the country.

From the above description want to see how Islamic investment and how to take advantage of capital. Investment is the active form of Islamic economics because each property is no zakat, if the property will be consumed gradually silenced by zakat, one of the lessons of charity is encourage for every Muslim to invest his money, the charity will not consume invested assets, but the benefits are.

We know the price of the investment, the price is the value of the sale or purchase of something that traded, the difference between the purchase price to the selling price is called the profit margin, price formed in the aftermath of the market mechanism.

Al-priest according to Al-Ghozali, profit is the compensation of the exhaustion of travel, business risk and personal safety threats entrepreneurs, so it is reasonable for someone to gain the benefits of risk borne compensation.

According to Ibnu Taimiah, offers could come from domestically and imported products, changes in supply described as an increase or decrease in the number of goods on offer, while the demand is very determined and revenue expectations, depending on the size of price increases and the magnitude of changes in supply or demand. When all transactions are by the rules, the price increase happens God"s will.

Islamic principles in muamalah that must consider by the perpetrators of Islamic investment:

1. Rizki not looking at forbidden things, both regarding substance and how to get it, and do not 
use it for things that are forbidden.

2. Do not oppress and do not tyrannized

3. Fairness distribution of prosperity

4. Transactions carried out by the same pleasure pleasure

5. No element of usury, gambling, and obscurity

\subsection{Mudharabah}

Mudharabah is allowed based on the Qur" an, Sunnah, ijma, and qiyas Allah says in the Qur" an al- Muzammil ;20:"Others traveling through the land seeking of Allah"s bounty" and AIQuran Chapter al-Jumu" ah 10:verses "And when the Prayer finished, then may you disperse through the land, and seek of the Bounty of Allah". Prophet of Muhammad handed over to the Jews of Khaibar palm groves and fields Khaibar area that they do it at their own expense and the result divided by two (HR.Bukhari 2329 and Muslim 15151). In Mudharabah justice must be realized because both feel the benefits and bear the loss From ljma, narrated from the Jamaah from the companions, that they give the orphan" s property to be mudharabah it and no one would deny. According to qiyas, mudharabah can analogy with musical because of the needs of the community. Mudharabah divided into two:

- Mudharabah Muthlaqah, cooperation between owners of capital with the business manager without being limited in determining the type of effort, time and territory.

- Mudharabah Muqayyadah, restricted mudharabah/specified mudharabah or the opposite of Mudharabah Muthlaqah. Application in banking Applied to finance products and financial On the fundraising side mudharabah applied to Savings deposits, for special purposes, such as Hajj savings, deposits and other ordinary - Special deposits (special investment), for certain businesses, such as any mudharabah, ijarah only. On the side of financing applied to Working capital financing, such as working capital and trade services - Special investment, such as Mudharabah Muqayyadah Benefits Mudharabah. Banks will enjoy increased profits if the profit sharing increased business manager - The bank is not obliged to pay for the results to be permanent fund manager-.Return of principal financing tailored to the cash flow business manager - Banks will be more selective search for lawful and profitable businesses Risk Mudharabah: - Side streaming, business manager does not use the funds referred to in the contract - Negligence and willful misconduct - Concealment of profits by managers when dishonest

\section{Tenets of investment business}

1. Two or more actors Investors and managers of capital. Both are required to have competency activities; people who are not in a state of bankruptcy debts. People who go bankrupt debt, the crazy, small children who are minors it should not execute this transaction. Investment is the pagans, Jews, and Christians who can be trusted, but the Muslims should monitor it to the business conducted on the issue of permitted investments by Islamic teachings. 2. Transaction object Capital Capital requirements should be a medium of exchange, such as gold, silver or money in general. Investment should not be made using the goods because the lack of clarity in the division of profits unless the price of goods determined by the value of money and the value that is used to start a business. Investors may be adding fresh funds into the capital invested, with its conditions must be clear so that the pros and cons. But if he gives new capital after the first operation of the bargain capital, and capital required to mixed with the first, it should not be. As a consequence of the addition of the losses with gains another. - Business Origin of the investment business is in the field 
of commerce or other related fields. Business system investments are sometimes free, sometimes have certain criteria. Businesses with free investment are by way of handing money to the organizer without specifying the type, form, place and time and effort to coordinate with partners. Capital managers may hire other people to do things that do not have to work themselves out of business, as it offers merchandise, moving goods to warehouses and other storage.

Managing capital, if authorized by the owner of capital or assigned capital to take care of it with his ideas, he should just invest it back to others. A capital manager who has been given full authority to manage one" s capital may invite others to ally with the capital was. Managing capital is not entitled to buy more goods than for capital investment because it means that he adds the responsibility of the owner of capital without the consent.

\section{Benefit Laws}

a. Terms of profit Cleary known, the percentage should be affirmed, as a half, a third, a quarter

b. Profit sharing code of conduct Profits based on the agreement of both parties, but the loss is borne only by the capital alone, because it is a loss that showed reduced expression of capital, and it is a matter of capital owners, managers only power loss.

c. Used as reserve capital gains Managers are not entitled to receive benefits before he handed back the existing capital because it is the excess profits of capital. If it has not become an extra, it not called profit. If there is an advantage on one side and a loss, on the other hand, the losses were to covered in advance with the advantage that there is, then the two remaining divided according to an agreement.

d. Managers should not take advantage before the division Managers has the right to participate in profits merely looks yes profits. But managers retained the rights to the division at the end of the agreement, no rights for capital managers to take his share of the profits are there except the official end of the division. And sharing it only with the permission of the owners of capital. Reason for not allowing for capital managers to take his share of the profits until after the division is as follows: May occur after the loss, so that the profits are used to cover it, as has been explained as a function of the profit of capital reserves

e. Rights would not benefit either party obtained before the end of the calculation of the business. Actual ownership of each party to the profits distributed is unstable right and will not be permanent and filtered before finishing entire agreement with the existing establishment. The final calculation permanent ownership advantages, its application can be of two kinds: First, the calculation of the end of the business, namely the way that capital owners can take back their capital and completed the cooperation ties between the two sides. Second, finish cleansing against profit calculations, i.e. by reducing assets and present and set its value numerically, where the owners of capital if he wants to take it. But if he wants to play again, means it must be a new business agreement, not to continue the effort.

Operational Fund Manager Managers can take him from the operational funds for venture capital when He was on the way, according to the custom world trade.

Responsibility for managing the investment of capital No responsibility for the management of the venture capital except for negligence or violations, together with the responsibility of those who are giving something.

Way to use based business in the world of investment banking Modern Islamic banking has been utilizing the services of this establishment and be a driving force in the development of capital projects. Banks play a role as a manager in the management and development of capital to distributed to various locations capital development. Parties should be engaged in the business of 
investment banks acting as manager before the owners of the funds that act as a nursery. Cooperation can be a partner, lender depending on the character of the business which binds both parties. This form of cooperation tied with some belief, the lack of responsibility of the manager of the venture capital investment except for negligence or breach, so does not differ investment business through investment banking services with otherbusinesses.

\section{3. ljarah}

ljarah is etymologically meant wages and provide jobs. And this word became popular as a term of a contract. Allah said in al-Qur" an an-Nissa 74. Let those fight in the cause of Allah who sells the life of this world for the Hereafter. To him who fights in the cause of Allah whether he is slain or gets a victory soon shall We give him a reward of great (value) In al-Qur" an al-Baqarah 233, Allah said:

The mothers shall give suck to their offspring for two whole years if the father desires to complete the term. But he shall bear the cost of their food and clothing on equitable terms. No soul shall have a burden laid on it greater than it can bear. No mother shall be treated unfairly on account of her child; an heir shall be chargeable in the same way. If they both decide on weaning, by mutual consent, and after due consultation, there is no blame on them. If you decide on a foster-mother for your offspring, there is no blame on you, provided you pay what you offered, on equitable terms. But fear Allah and know that Allah sees well what you do.

According Syara' ljarah is a contract that contains a provision of benefits to compensate for certain conditions. ljarah can also define as an agreement on the desired benefits, it is known, can be submitted, and is permissible to compensate the unknown. When the process has been perfect ijarah agreement, then the deal is fixed. Each party held not entitled to cancel the contract unilaterally contract unless found defective. ljarah contract term shall not include a requirement choose because it prevents the use of the right. There are four pillars of ijarah, i.e., two sides held a ceremony, greeting ijara, rewards, and use rights or benefits. Non-Muslim is legitimate to conduct ljarah agreement with Muslims, as has been done by Ali on ijarah in the form of a dependent. Regarding leasing, tangible goods required wage must know the type, level, and nature, as the price of the contract of sale, as ijarah contract is for-profit, which is not valid without mentioning the value of compensation like buying and selling.

ljarah or sale of services is a transaction object a benefit or services or permissible in law and the benefits known in the clear timeframe and with a clear rent. Including ijarah transaction binding both parties to the transaction that the buyer and seller services. Meaning that one of them should not cancel the transaction without the consent of both parties. There is a wide ijarah, ijarah with the transaction object particular object, for example, rent a house, car, and ijarah transactions with objects specific job, for example employing people to build houses and others.

In ijarah a worker entitled to wages or salary if he has completed the job perfectly and professional obligations. Such workers must be paid their wages, so the work is completed, the goods are damaged due to accidental workers are the responsibility of the owner of capital. If we are worried about saving in the bank, then we can lend to people who can be trusted to be developed as the capital of the profit-sharing system.

\section{Methods}

In this paper, the author tried to lift gold and pearl merchant behavior in investing in Mataram city 
Lombok West Nusa Tenggara Indonesia. Reason for choosing gold and pearl merchant as a case study objects, because this business done in down-dropped and contributed significantly to the region, especially in absorbing labor. The merchant development of regional tourism and the number of the largest traders of gold and pearls are in the city of Mataram, in addition to the provincial capital, Mataram is the first city where gold trades mainly in districts Sekarbela.

The research method used was a qualitative study, the data source is the documentation and field data. Research procedures, conduct in-depth interviews with the head of gold and pearls and merchant association, community leaders and religious leaders and merchants. Development of gold traders in the city of Mataram began in 1984 with marked many gold shops and pearls. 80 percent of the gold traders dominated by native Sekarbela which is one area in the city of Mataram. To see how the behavior of trading and investing writer interviewed several informants directly in the field. Trade is an economic activity that can occur in the form of exchange, sale, manufacture, marketing, work and hiring and other human interaction to obtain a profit. Business conditions now tend to conflict with the islamic law does not heed the ethical or moral values. Attention to business ethics with the rest of the business itself, since humans engage in commerce, we realized that these activities could not separate from ethical concerns. For example, since the human trade he knew about the possibility of fraud. Honesty, fairness, accuracy in the promise, not usury, and not precede each other in offering goods which run by traders of gold and pearls cannot be formed by itself, but there are other factors besides normative factors outlined by the Qur" an and hadith.

Three factors can affect an individual" $s$ behavior is the interpretation of the legal, environmental or organizational factors, individual factors, and circumstances (Rafik Issa Beekun in Badroen Faisal et al. 2006:59). Interpretations of the legal, philosophical, legal system established to protect the human body and soul of a variety of factors that can eliminate human existence. Law and are believed to be living presence is no benefit to humans. The behavior of gold and pearl merchants also bound by existing law, both state and religious law. Environment or the organization in which he lives, the behavior of the traders of gold and pearls cannot separate from the activity in the environment, if the environment all business with honesty, fairness, it will form business conduct and fair. The last factor individual inner experiences, experienced by traders gold and pearls, suppose a trader who has accustomed. To be honest in trade, then he will be the one who loves honesty, otherwise, if you are already familiar with the behavior of dishonesty, then the weight for him to act honestly in trade. Most guidelines for trade and investment principles to be followed by traders of gold and pearls is Annisa letter Qur" an verse 29: "O you who believe! Eat not up to your propertyamong yourselves in vanities: but let there be amongst you traffic and trade by mutual good-will, nor kill (or destroy) yourselves; for verily Allah has been to you Most Merciful" Based on the testimony of gold and pearl traders we interviewed in the field said: a merchant named T ( pseudonym), said." I explain merchandise to the buyer with the actual, on the scales I have always tried to weigh rigorously,. T he agrees with the buyer always my keep, I never precede each other with other merchants in offering goods. The narrative is more interesting than a dealer named B (pseudonym). My first ever trade dishonestly to explain the actual merchandise. That is not primarily in terms of scales and levels of gold, it turns the situation cannot last long, I often have trouble when purchasers or customers returning goods caused by my own, I finally realized that the lie does not bring benefits and tranquility, so I trade with the Islamic way, Thank God the results are better. Regarding investment in gold and pearl, traders realize that multiply wealth of activities not prohibited in Islam, even Islam strongly recommends that property investment that one has to be more productive and bring benefits to others. Otherwise, the treasure hoard activity was forbidden by God because of 
idle funds not provide benefits. Gold and pearl traders do not invest their money in the stock market, but channeling capital to traders of gold and other pearls with a profit-sharing system at the end of the year with the distribution of 40 percent to 60 percent for traders and owners of capital. Normatively gold and pearl traders have applied already implemented a system to invest their capital in the mudharabah. Meaning that they assist each other in developing trade and capital. Besides mudharabah also ijarah or wage system has been implemented by traders, which employs people. Gold and pearl merchants, ijarah form done by employing labor to serve the buyers or subscribers. Each trader employs two workers with wage 50 thousand rupiahs per day. Contribution to the development of economic gold traders Mataram is helpful in employment, supporting the development of West Nusa Tenggara Tourism, both domestic and abroad, especially in the area of increased income tax payments, an increase in the welfare of the community with many traders who perform the Hajj. So gold trader in an investment carried out by Islamic ijarah and mudharabah. They are not invested with interest because they think that interest is riba, they often hear associated with muamalah recitation and practice in the field of trade and investment.

\section{Result and Discussion}

The research results are obtained based on the steps of preparing accounting information system are consisted of four focuses that are (1) Analyzing the existing accounting information system, (2) Planning the accounting information system, (3) Applying accounting information systems, and (4) Supervising the new system.

\subsection{Analyzing the Existing Accounting Information System}

This step is intended to determine the weakness and the strength of the existing system. This study performed a preliminary observation which aims to establish the scope of work and plan the period to prepare the system [14]. Analyzing steps of accounting information system carried out in the trading SME involves two things, i.e., an understanding of the business processes and evaluating the weaknesses and the strength of exiting the system.

12 trading SMEs that have become the focus of this research, all are had a superior product variation as their trademark. Following the characteristics of a trading company that does not change the form of goods, the types of product sales are range from retail stores, selling cassava or yams, selling building materials, sacks, glassware or potteries, and veils. The result associated with the legal form of the business showed that 11 of 12 trading SMEs are in the form proprietorship companies and one SME in the form of CV. Meanwhile, the results related to the amount of daily sales turnover of 12 trading SMEs can be classified as follows.

Table 2. Data Classification Based on Daily Sales Turnover

\begin{tabular}{ccc}
\hline Classification & Daily Sales Turnover & $\begin{array}{c}\text { Number of Trading } \\
\text { SMEs }\end{array}$ \\
\cline { 3 - 3 } Micro & < Rp. 900 thousand & 2 \\
Small & Rp. 900 thousand - < Rp. 7,5 thousand & 9 \\
Medium & Rp. 7,5 thousands - < Rp. 150 thousand & 1 \\
& Total & $\mathbf{1 2}$ \\
\hline
\end{tabular}

Source: Data analysis

Table 2 indicates two trading SMEs categorized as micro-enterprises, nine SMEs classified as small enterprises and one SMEs as businesses in the medium level. The observation results also showed only 
one of 12 trading SMEs that has become the member of the cooperative. The participation as a member of cooperative has become one of the interviews elements with the assumption that as a member of a cooperative, SMEs have access to the funding sources as well as obtain supervision from local cooperatives or Ministry of Cooperatives, Small and Medium Entreprises. The result also illustrates that in operation, the majority of trading SMEs use their private capital rather than debt considering the type of legal entity as proprietorship companies.

Table 3 shows the results of research related to the general description of the accounting information system and internal control activities are carried out in 12 trading SMEs. Before design the appropriate accounting information system, it is necessary to understand the business processes of trading SMEs. Reference [9] underlined that the understanding of AIS within the organization aimed to comprehend whether the existing system has achieved considerable cost savings, the ability to increase the solution creation as it allows a continuous improvement, correct or update the procedures and able to make adjustments following best practices.

Table 3 also indicates that $83 \%$ of trading SMEs surveyed has no clear organizational structure. As a result, the companies do not have clear segregation of duties and authority. In general, most of trading SMEs have simple finance, and accounting manuals, at least they have the cash and bank revenues or disbursements. Bookkeeping functions did not separate completely from the cash receipts and disbursements' function, purchasing function, and inventory functions because of limited available resources regarding quantity or inadequate competence human resources. All personnel who takes regular leave rights handed over routine tasks and all the responsibilities to other staff. Although the job of bookkeeping is rotated by other employee and due to the time limit, the rotation has not sufficiently revealed the irregularities. One reason is the company owned and managed by family members thereby weakened the monitoring activities carried out by the owner.

Furthermore, the use of computer tools for bookkeeping is still a minimum. Most of the accounting activities performed manually. If the SME is using the computer, the data security level is still low because of shared access to the computer. The company also has not had a security guard to check every person or vehicle in and out of the company's locations. Simple financial reports are made periodically to the management. $63 \%$ of trading SMEs surveyed have not been using adequate budgeting as a tool to control expenses and costs. Meanwhile, approximately $58 \%$ of trading SMEs surveyed have a trade partner or supplier who maintained privileged. The average transaction carried out in trading SMEs is based on the cash basis so that the company mostly does not have the term of credit agreement. 
Table 3. The Description of Trading SMEs Accounting Information System

\begin{tabular}{|c|c|c|c|}
\hline \multirow[t]{2}{*}{ A. } & \multirow[t]{2}{*}{ Indicator } & \multicolumn{2}{|c|}{ Disclose } \\
\hline & & $\begin{array}{l}\text { Yes } \\
(\%)\end{array}$ & No (\%) \\
\hline 1 & The existence of organizational structure & 17 & 83 \\
\hline 2 & The company has the personnel job descriptions & 42 & 58 \\
\hline 3 & $\begin{array}{l}\text { The company has the financial and accounting } \\
\text { manual }\end{array}$ & 50 & 50 \\
\hline 4 & $\begin{array}{l}\text { Bookkeeping functions are sufficiently separated } \\
\text { from cash receipts and disbursements, purchasing } \\
\text { and inventory functions }\end{array}$ & 50 & 50 \\
\hline 5 & $\begin{array}{l}\text { All personnel regularly take his leave right and left his } \\
\text { regular duty to other personnel }\end{array}$ & 58 & 42 \\
\hline 6 & $\begin{array}{l}\text { Other staff rotated bookkeeping tasks, and there is } \\
\text { enough turn time limit to reveal irregularities }\end{array}$ & 8 & 92 \\
\hline 7 & $\begin{array}{l}\text { Companies already processing bookkeeping with } \\
\text { computer, location, and access to the equipment } \\
\text { are accessible only by authorized personnel, and } \\
\text { computer input source based on transaction } \\
\text { document }\end{array}$ & 33 & 67 \\
\hline 8 & $\begin{array}{l}\text { Financial statements periodically provided to the } \\
\text { management }\end{array}$ & 33 & 67 \\
\hline 9 & $\begin{array}{l}\text { The use of budgeting system to control costs and } \\
\text { expenses }\end{array}$ & 67 & 33 \\
\hline 10 & The existing partners or suppliers particularly retained & 42 & 58 \\
\hline 11 & $\begin{array}{l}\text { Companies have security guards to check every } \\
\text { person or vehicle in and out of the company's } \\
\text { locations }\end{array}$ & - & 100 \\
\hline 12 & The company has branch offices & & 25 \\
\hline 13 & The supervision of the branch has done effectively & 33 & 67 \\
\hline 14 & $\begin{array}{l}\text { The credit process should have approval from } \\
\text { related authorities }\end{array}$ & 17 & 83 \\
\hline 15 & The company has the terms of credit agreements & 25 & 75 \\
\hline 16 & $\begin{array}{l}\text { The company has written internal policies, all minute } \\
\text { meeting for decisions, the managers or directors } \\
\text { meeting are well documented and signed neatly }\end{array}$ & 17 & 83 \\
\hline
\end{tabular}

Table 4 describes cash or bank system revenue and disbursements method implemented in the trading SMEs. The administration of cash or bank revenue and disbursements is orderly arranged because of the finance officer stores the chequebook and bank deposit books in an organized manner. Each cash or bank receipts recorded immediately. Bank reconciliations did not always implement under one or both of these two conditions, i.e., first, the accounting records of the companies are similar to the bank, or second, the employee who is responsible for doing the bank reconciliation does not reconcile due to the limitations of their competence.

Table 4. Cash / Bank Revenue and Disbursement of Trading SMEs

B.

Indicator
Disclose 


\begin{tabular}{clcc} 
& & Yes (\%) & No (\%) \\
\cline { 2 - 4 } 1 & $\begin{array}{l}\text { Personnel who is responsible for processing and recording the } \\
\text { receipt of cash or bank does not have the authority to process } \\
\text { account receivables and petty cash }\end{array}$ & 17 & 83 \\
2 & $\begin{array}{l}\text { Cheque register and bank transfer receipt stored in an orderly } \\
\text { manner }\end{array}$ & 83 & 17 \\
$3 \quad \begin{array}{l}\text { Independent personnel periodically prepare Bank } \\
\text { reconciliations }\end{array}$ & 8 & 17 \\
$4 \quad \begin{array}{l}\text { Any cash or bank transaction recorded immediately } \\
5\end{array}$ & $\begin{array}{l}\text { Deposit to the bank performed by personnel who are not } \\
\text { related to the task of processing and recording bank receipt }\end{array}$ & 17 & 83 \\
6 & $\begin{array}{l}\text { Every revenue immediately deposited to the bank, and all } \\
\text { transaction properly recorded in an orderly manner }\end{array}$ & 83 & 17 \\
7 & $\begin{array}{l}\text { Cash revenue and disbursement is reported periodically to } \\
\text { management }\end{array}$ & 17 & 75 \\
8 & Budgeting system controls all expenses & 25 \\
\hline \hline
\end{tabular}

Source: Data analysis

According to the hadith, we are encouraged to have an honest nature. One of the most important moral nature of man is honesty because honesty is fundamental happiness of society. Honesty involves many aspects, especially related to all matters of life and the welfare of the community. As well as honesty in the case of cash management, cash has a very vulnerable nature as it can be easily transferable without any substantial evidence. Therefore, cash receive and disbursement should be managed as best as possible, efficiently and accountable by providing the evidence without any engineered irregularities. As it can be seen by the Hadith of Bukhari, "Be you all to be honest, because honesty leads to the goodness, and goodness brings to heaven". God will write a person who is always honest and searching for honesty as an honest man (Siddeeq). And avoid lying, because lying leads to evil, and evil brought to hell. People, who are always lying and looking for lies, will be written by God as a liar (Al Kadjab )" [15].

The Qur'an Surat Al-Hujurat verse 6 also highlights the importance of supervision and inspection functions (control and audit) in all activities to avoid disaster for others: "O you who believe! If an unrighteous person comes to you with information, you should verify it or else you might inflict harm on a people in ignorance and then end up regretting what you have done" [16].

If someone holds the position, he or she should be able to maintain and responsible with "Amanah" or trust, not cheating as well as honesty and knowledgeable because it will bring a lot of trust from the others, as the story of Prophet Yusuf described in the Qur'an Surah Yusuf verse 55 as follows. "[Joseph] said, "Appoint me over the storehouses of the land. Indeed, I will be a knowing guardian" [17].

Regarding receivables transactions, as described in a general overview, the trading SMEs conducted the majority transactions in cash-based. Companies do not have account receivables card for each customer since credit in sales are rarely implemented, and as a result, the record of accounts receivable per customer is not examined periodically by late payment.

In Islamic law, debt or loan has known as Al-Qardh. Al-Qardh meaning in etymology (language) is Al-Qath '(disconnected). An asset handed over to the person who owes called Al-Qardh because he was cut off by people who are owed money. While according to the Islamic terminology, AlQardh means handed asset (money) as a form of affection to anyone who would use it and in 
return, he would pay back at a time following its equivalent. Initially, the law of debts and receivables are allowed in Islamic law. Giving a loan to someone else who needs it is preferable and recommended because there is a great reward in it. As it revealed in Al-Qur' a Surah Al-Baqarah verse 245: "Who is it that would loan Allah a goodly loan so He may multiply it for him many times? And it is Allah who withholds and grants abundance, and to Him, you will be returned" [18].

Furthermore, the feature of inventory in trading SMEs is the inventory that used as a selling product without changing its shape. Inventories are the assets of the company which occupies an important position in a company, whether it is the trading company or manufacturing company. For a company engaged in the construction field, almost $50 \%$ of the company funding will embedded in the inventory that is to buy building materials [19]. The company has inventory to ensure a smooth business. For a trading company, the availability of merchandising inventory allows the company to meet the demand of the buyers.

The results showed that $83 \%$ of trading SMEs have already managed their inventory in a neat and orderly manner and prevent it from theft, damage, fire or other risks. The company also conducts a simple recording of inventory, for example in the form of an inventory card or notebook to record inventory turnover. Although simple, the inventory transactions well documented. All distributed merchandising to the customers must conform to the distribution letter and must be authorized by the company official. Similarly, damaged goods are separated and recorded separately. However, the real calculation has not carried out routinely. Furthermore, due to limited human resources availability, the result indicated that $75 \%$ of trading SMEs do not have the inventory's supervisor to oversee the company warehouse.

It is necessary to implement the high internal control related to fixed assets to support the accounting information system that aims to facilitate and the accuracy of decision-making processes. The results showed that the addition or subtraction of fixed assets on trading SMEs had not duly authorized during the recording, although there are several trading SMEs already performed adequate maintenance, security, and insurance for assets. Given the urgency of fixed assets of the business flow, $83 \%$ of trading SMEs did not have the list of fixed assets yet as one of the control tools. The depreciation has not implemented, and there were no reviews regarding the existence of damaged fixed assets or idle capacity of fixed assets.

\subsection{Planning the Accounting Information System}

This phase described whether there would be a design of a new system or changing the old system to eliminate and to reduce the weaknesses. There are two different methods to plan the system, using the top-down approach and bottom-up approaches. Both of these approaches selected considering the condition of the company. The sequence of work for a top-down approach is the identification information, account classification and grouping of code included in the general ledger and sub-ledger, journal planning, planning transaction evidence and procedure planning. While the order for a bottom-up approach is starting from planning the transaction's evidence including procedures, planning of journal, planning of account classification code and ends with the resulting information, including forms of the report. The preparation of the accounting system to an organization should consider principles such as speed, security, and the principles of the economy [14]. The design of AIS for trading SME trade based on the understanding of the business processes, the weaknesses, and the strength analyses discussed as follows.

The existence of a clear organizational structure within an organization represents to whom the performance responsibility aimed to determine whether there is a line of authority or organization 
staff. Certainty associated with the work condition can determined by translating the organization chart. If the chart or organizational structure is not available, then it should be made in advance. The organizational structure can be used to define the lines of authority and the job responsibility. Many organizations do not know the importance of organizational structures in developing employees to function properly [14].

The job description is a written statement that contains a description of what needs to be done by the personnel, how a job and why the job done. The description contains about the relationship between a particular position with other positions inside and outside the organization and scope of work in which the personnel is expected to contribute to achieving the goals set by division or business unit as a whole. Thus, job descriptions will make the job can run better and more efficiently.

The chart of accounts is a list of codes for all the estimates transactions included in the company ledger. The chart shows the structure of a company's financial data, which is useful for generating detailed information for the presentation of financial statements [14]. The classification of ledger account based on the group of accounts. Each group has a specific code. The code will divide the data into particular groups and tailored to the order of presentation of information in the Balance Sheet and Profit and Loss calculation. Each group will be coded with numbers so that each digit position has the meaning.

The surveys on transactions have been carried out to determine journals and ledgers used in trading SMEs. Transactions between trading SMEs can be different according to the characteristics of the business process of each company. Phase preparation of journals and ledgers used is a core phase of the entire arranged accounting system. The design journals and ledgers should consider the materiality of decision-making level and the importance of transparency, accountability, and reliability of the produced financial statements.

Trading SMEs can use the Financial Accounting Standards Entities without Public Accountability (SAK ETAP) issued by IAI [20]. This SAK is designed to assist SMEs in preparing financial statements. The purpose financial statements are to provide information about the financial position, financial performance, and cash flows of an entity that is useful to a large number of users in making economic decisions by anyone who is not in a position to ask for financial reports to meet the specific information needs. Financial statements also show what has been done by the management (stewardship) to achieve the objectives or the accountability of management for the resources entrusted to them [20].

Full financial statements by SAK ETAP include the balance sheet, income statement, statement of changes in equity, cash flow statement and notes to the financial statements which contains a summary of significant accounting policies and other explanatory information. Minimal information in the balance sheet includes cash and cash equivalents, accounts receivable and other receivables, inventories, investment property, fixed assets, intangible assets, accounts payable and other debts, assets and tax liabilities, estimated liabilities, equity. Minimal income statement includes the following items: income, financial expenses, profits or losses sharing from investments using equity method, tax expenses, net income or loss [20].

The accounting policies applied in trading SMEs as the focus of research is at least complying the standards set out in the SAK ETAP [20]. The following are the examples of accounting policies can be performed in trading SMEs.

1. Petty Cash

a. Petty cash fund is cash available to pay the expenses which are relatively small and uneconomical if paid by check. 
b. The total amount of petty cash stipulated for certain amount every week or month adjusted for the company's business activities

c. The recording of petty cash used fixed funds system (imprest system). In this system, the number of petty cash accounts always fixed as approved by the board of directors.

d. The petty cash cashier must provide the evidence of expenditure every time he or she makes a payment. At the time of refill, petty cash cashier will hand over the evidence of expenditures and received a check/money for expenses already paid.

e. Petty cash refill will done if the total spending of petty cash has reached $70 \%$ of the maximum amount of petty cash.

2. Account Receivables

a. Account receivables presented in the financial statements recognized at the realizable cash value

b. Bad debt Expense. It is necessary to form the allowance for doubtful debts to anticipate losses for doubtful account receivable. The determination of the allowance for doubtful debts can be based on a percentage of credit sales or by other general provisions.

3. Inventory

a. Equipment inventories recorded at cost, i.e., the purchase price plus the cost of buying those inventories

b. Equipment inventory system recorded using the perpetual method. In this approach, each revenue and expenditure mutation has registered so that the balance of the value and quantity of the inventory can determine at any time.

c. Measurement is using the FIFO (First in First Out) or the average method by SAK.

d. At the end of the annual period, the inventory will performed. If there is any difference between the accounting record and physical position of inventory, it will be recognized as a gain or loss to another depending on the difference more or less.

\section{4. $\quad$ Fixed Assets}

a. Estimation of Economy Age and Fixed Assets Depreciation

Fixed assets recorded at cost includes all costs incurred until the assets are ready for use. Selfconstructed assets recorded at the entire value of materials/equipment used. Meanwhile, depreciation of fixed assets is calculated using the Straight-line method, based on estimated useful lives, as follows

Table 5. Fixed Assets Depreciation Rate

\begin{tabular}{clcc}
\hline No & Type of Tangible Fixed Assets & Useful Life & Depreciation \\
\hline 1. & Building & 20 years & $5 \%$ \\
2. & Equipment & 4 years & $25 \%$ \\
3. & Vehicle & 8 years & $12,5 \%$ \\
\hline \hline
\end{tabular}

b. Fixed Asset Expenditure

The expenditure on fixed assets for maintenance, addition, renovation, expansion aimed to add economic value, increase the capacity and increase the useful life will be capitalized to add the value of the assets. 


\section{Debt}

Debt is valued based on purchasing credits, loans from other parties with a certain amount of interest, the expenses have occurred, are presented on the balance sheet following the obligations of the company to the vendor creditors and other parties.

\section{Revenue Recognition}

Revenue recognized at the time of incurred (acceptable) based on valid evidence.

\section{Expenses}

The expenses should be recognized, recorded and reported for the period of the transaction. Payment for periodic transactions such as salaries, electricity, rent, and insurance must attribute to the period in which such expenses occurred, even if payment has not been made or has paid in advance. For the purposes accounting period cutoff, expenses incurred before the date of the balance sheet although not yet known with a certain amount should be recorded and reported with a reasonable estimation.

The following is the example of the procedure or mechanism that can be used to facilitate accounting information system of trading SMEs adopted from Mulyadi [21]

1. Procedures that form credit sales system consists of the procedure of sales orders, credit approval procedures, delivery procedures, billing procedures, procedures for recording accounts receivable, sales distribution procedures, record-keeping procedures of goods sold.

2. Purchasing procedures are comprising a purchase order procedure, procedure requests for quotation and supplier selection, procedures of receiving goods, debt recording procedures, the purchase distribution procedure

3. The procedures that are forming payroll and remuneration system comprise recording of attendance procedures, the procedure of preparing payroll, payroll expense distribution procedure, the procedure of providing cash outflow evidence, and procedure of payment ofsalaries.

4. Procedures that are forming the system of revenue from cash sales consist of sales order procedures, procedures for cash receipts, goods delivery procedures, procedures for recording cash sales, cash deposits to bank procedures, procedures for recording cash receipts, recording cost of goods sold procedures.

5. Procedures that are forming cash disbursements include the system does not require a cash disbursement check requests and those systems that require a cash disbursement check request

6. Procedures that are forming inventory system consists of inventory recording procedures, procedures for recording the cost of supplies purchased. Procedures for the cost of inventory returned to the supplier, procedure for requests and distribution of inventory from the warehouse, procedure for recording the additional cost of inventories due to the return goods, and procedures for physical inventory .

7. The subsystems that are forming the accounting system of fixed asset consist of fixed asset purchasing system, fixed asset acquisition system through its development, capital expenditure systems, discontinuation fixed assets systems, fixed asset transfer system, the system of fixed assets revaluation, and accounting system of fixed asset depreciation.

Meanwhile, the document transactions can be in the shape of a form and recording document 
that routinely used in all organizations. Documents can be in the form of electronic or non-electronic. This document aimed to establish responsibility and as evidence of transactions occurred [14].

Reference [21] highlighted that document or form has the following benefits: assign responsibility for the emergence of the company's business transactions. The regerence also contains data recording of business transactions of the company, reduce the likelihood of error by declaring all the events in writing, and delivering basic information from one person to another within the same organization or to other organizations.

Some basic principles need to consider in designing a form for the company's business activities, namely: (1) providing the copy or copies of the form, (2) avoid duplication in data collection, (3) make the form as simple and concise as possible, (4) Integrate the internal check in designing the form, (5) Include the company name and address on the form to be used for communication with external parties, (6) Include the name of the form for easy identification, (7) Give the numbers for a form for easy identification, (8) Include a line number on the left and right side of the form if wide form used, to minimize the possibility of incorrect filling, (9) Print out a line on a form, if the form will filled by hand writing, (10) Include printed serial number, (11) Design a specific form allowed the filler only write sign or $x$, or by answering yes or no, to save time in filling, (12) Prepare a double form with carbon insert disposable or NCR paper, (13) Using the distribution zones allowed the forms divided according to blocks of logical areas containing data related to each other [21].

\subsection{Accounting Information System Implementation}

The process of applying the new or revised accounting information system must have the approval from the management of trading SMEs. The commitment of management is also needed to encourage the implementation of a new information system.

The new system should implemented at the beginning of the accounting period. The goal is to reduce the workload arising from the changes that will influence account balances and the use of new procedures in the middle period. If the company uses computerized systems, the application of the new system can performed in conjunction with the old system. Therefore, two systems process the same data. The intended use of the two systems in parallel is to prevent the emergence of new difficulties because the system can not function properly, thus at the same time can generate two types of information. Both types of information from these two systems can be compared to check the results of the new system processing [14]. If the new system has been tested and settle down, the company can be started not to use the old system.

\subsection{The Supervision of New System}

This phase has an objective to supervise the application of the new system, to verify whether the new system can function properly. If it found an error, then during the period of supervision, it is necessary to make the improvements. The focus of the new system does not repeat existing weaknesses in the old system [14].

\section{Conclusion}

To conclude, trading SMEs as the focus of research has simple accounting information systems implemented in the business activities, but it has not well documented. The results of research on the business process and the analysis of the weaknesses and strengths of the system indicate that the applied accounting information system requires an improvement regarding organizational structure, 
job descriptions, internal control related to inventory and fixed asset management. These results are used as the basis of accounting information to design the new system to repeat the same mistakes in achieving corporate goals.

It requires a pilot model of accounting information system design at trading SMEs that can support the daily operations of the business. Therefore, it is necessary to conduct more accurate mapping of trading SMEs to support the accounting information system. Future research can be developed in the form of the increase in the number of SMEs surveyed, for examples focus on different business activities such as services or manufacturing companies. COSO framework specifically for SMEs can be the alternative for analysis.

\section{Acknowledgment}

We would like to thanks to all of the trading SMEs who participate in this research.

\section{References}

[1] Abdullah Yusuf (2005), the Holy Qur" an, Text and Translation, Islamic Book Trust Kuala Lumpur.

[2] Abdullah Al-Mushlih, Sahalah Ash-Shawi (2004), Fikih Ekonomi Keuangan Islam, Darul Haq, Jakarta (edisi Indonesia), 171 - 198. (Islamic Financial Economics Jurisprudence)

[3] Muhammad Syafi" i Antonio (2001), Bank Syariah, Dari Teori ke Praktik, Gema Insani Jakarta 137 139. (Islamic Bank, From Theory to Practice)

[4] Wahbah Al-Zuhaili (2011), Fiqih Islam Wa adilatuhu, Gema Insani Jakarta, 476 - 513. (Islamic Jurisprudence) 